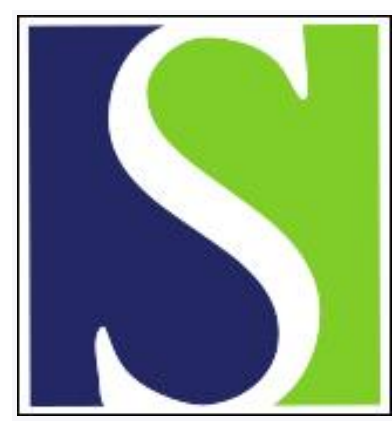

Scand J Work Environ Health Online-first -article

https://doi.org/10.5271/sjweh.3076

Published online: 05 Aug 2010

Well-being at work - overview and perspective

by Schulte $P$, Vainio $H$

Affiliation: National Institute for Occupational Safety and Health, Centers for Disease Control and Prevention, Cincinnati, Ohio 45226, USA.pschulte@cdc.gov

Key terms: discussion paper; health promotion; occupational safety and health; OSH; productivity; well-being; work; workplace

This article in PubMed: www.ncbi.nlm.nih.gov/pubmed/20686738

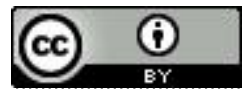




\title{
Well-being at work - overview and perspective
}

\author{
by Paul Schulte, PhD, ${ }^{1}$ Harri Vainio, MD, PhD ${ }^{2}$
}

\begin{abstract}
Schulte P, Vainio H. Well-being at work - overview and perspective. Scand $J$ Work Environ Health. 2010;36(5):422-429.

This paper provides an overview of and perspective on the concept of well-being at work. Well-being is a term that reflects not only on one's health but satisfaction with work and life. Well-being is a summative concept that characterizes the quality of working lives, including occupational safety and health (OSH) aspects, and it may be a major determinant of productivity at the individual, enterprise and societal levels. Based on a review of the literature and a recent conference, we suggest a model linking workforce well-being, productivity, and population well-being. To appraise the validity of the model, we consider five questions: (i) is there a robust and usable definition of workplace well-being? (ii) have the variables that influence well-being been aptly described and can they be measured and used in risk assessments? (iii) what is the nature of evidence that well-being is linked to productivity? (iv) what is the state of knowledge on the effectiveness of interventions to promote workplace well-being? and (v) should interventions aimed at improving well-being at work focus on more than work-related factors?
\end{abstract}

Key terms health promotion; occupational safety and health; OSH; productivity; workplace.

Maintaining the functioning of the workforce is increasingly a critical issue as workforces throughout the world age and worker shortages are projected due to lower fertility rates $(1,2)$. With these realities, nations are struggling to determine how they will meet social welfare, pension, and healthcare obligations, when the engine that supplies the financing - the workforce - is aging and increasingly impacted by chronic disease and disability (3-5). The key to maintaining the effective functioning of the workforce is the concept of wellbeing, which encompasses more than just one's state of health; it is also a reflection of one's satisfaction with work and life. This was recognized in what may turn out to be a landmark event, where 190 scientists and practitioners from more than 30 countries met on 10-12 February 2010 in Helsinki for the Towards Better Work and Well-being Conference, which focused on research and information on the well-being of workers (http://www.ttl.fi/en/press/Pages/pressrelease_5.aspx).

The conference highlighted the need to understand an array of factors that affect workers' well-being and the extent to which well-being influences productivity. Many of the presentations indicated that to address worker well-being and productivity effectively, the traditional focus of occupational safety and health $(\mathrm{OSH})$ must be expanded to include an understanding and assessment of those factors that lead to healthy, happy, and productive working lives.

The conference, sponsored by the Finnish Institute of Occupational Health, featured cutting-edge research on well-being at work, workplace health promotion, work organization, psychosocial and physical hazards, economic impacts, productivity, and intervention effectiveness. These topics were given perspective by repeated reference to the seminal work of Dame Carol Black's report, Working for a Healthier Tomorrow, and the close to two decades of research on the concept of work ability (a worker's physical, psychological, and social capacity to work) and the work ability index (6-13).

Well-being is a summative concept that characterizes the quality of working lives, and it may be seen as a major determinant of productivity at the individual, enterprise, and societal levels $(10,12-15)$. Productivity at those levels influences population well-being as illustrated in the heuristic model presented in figure 1. Critical in this model is the need for countries to maintain a viable dependency ratio (the ratio of dependents in a population to the size of the workforce). A viable

1 National Institute for Occupational Safety and Health, Centers for Disease Control and Prevention, Cincinnati, Ohio, USA.

2 Finnish Institute of Occupational Health, Helsinki, Finland.

Correspondence to: Dr P Schulte, National Institute for Occupational Safety and Health, Centers for Disease Control and Prevention, 4676 Columbia Parkway, MS C-14, Cincinnati, Ohio 45226, USA. [E-mail: pschulte@cdc.gov] 


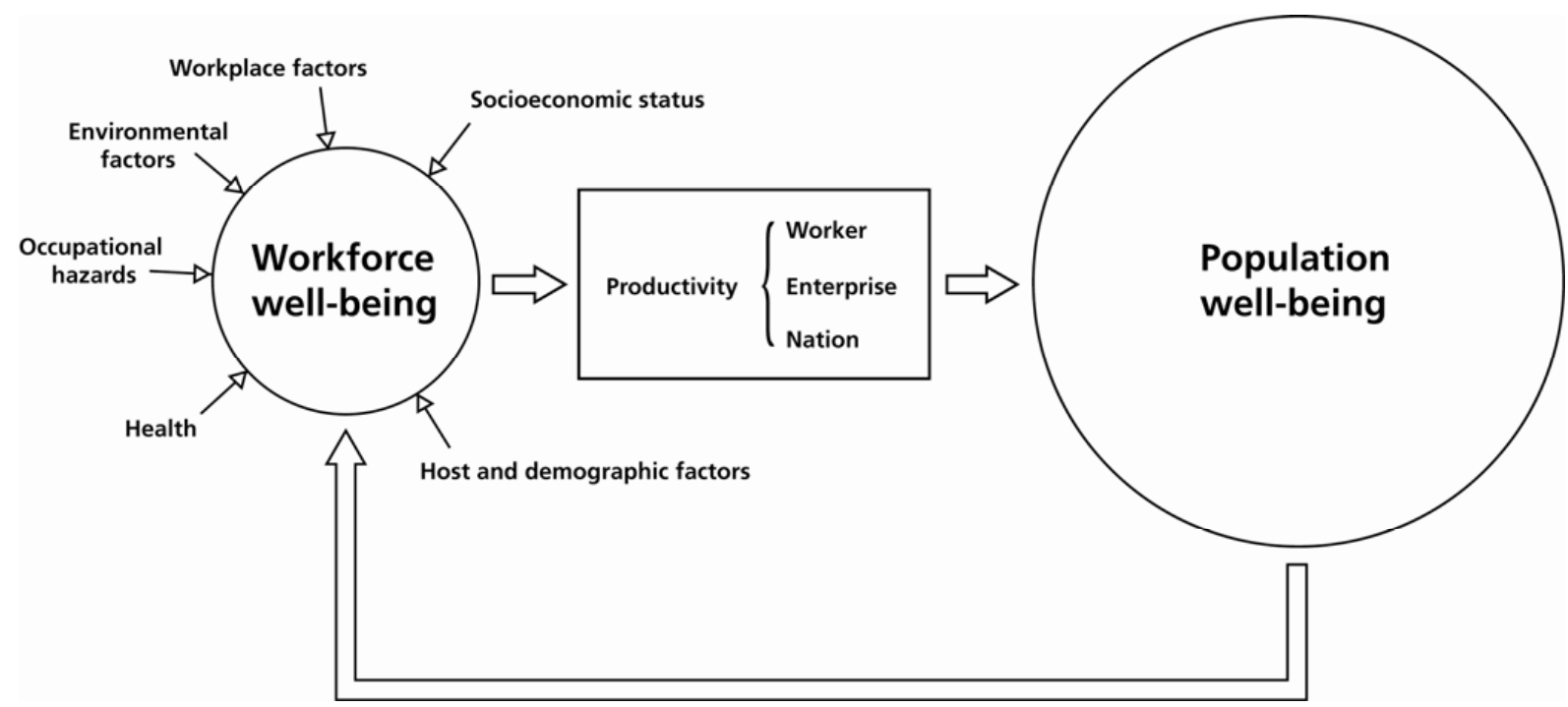

Figure 1. Relationship between workforce well-being, productivity (individual, enterprise, national), and population well-being: a heuristic model.

dependency ratio can be maintained by considering the needs of aging workers and the factors that keep them working $(16,17)$. More broadly, maintaining the productivity of workers, organizations, and nations requires understanding the relationship between the health and well-being of the workforce and the other factors that affect national economic growth $(14,18-21)$. Research and interventions to address health and well-being need to focus not only on individual level factors but more importantly on organization and societal-level factors as individual well-being does not exist on its own or in a workplace but rather within a social context $(12,15,21)$.

The nature of work can be both beneficial and harmful. Generally, most models in occupational health and well-being focus on job stressors and hazards and neglect the potentially positive effects of work such as income, engagement, personal growth, and learning (22-24). In contrast, in addition to occupational hazards, the absence of work (unemployment, or underemployment), is known to be a major stressor and cause of ill health $(25,26)$. In the evolving economies of the world, work and unemployment are part of a dynamic pool. In some cases, such as in the current economic recession, unemployment is involuntary. But increasingly workers may voluntarily or involuntarily face repeated cycles of education, work, leisure, and not working. Although these cycles may be desirable to some, they may also subject workers to the stresses of uncertain employment, new employment, or no employment $(25,26)$.

A general model that links workforce well-being, productivity, and population well-being is shown in figure 1. Although more research is needed to identify critical factors in well-being and the relationships between well-being and productivity, it is clear from existing data that the general elements of the model are important. To appraise the validity of the model, we pose five questions that might be helpful to consider: (i) is there a robust and usable definition of workplace well-being? (ii) have the variables that influence wellbeing been aptly described, and can they be measured and used in risk assessments? (iii) what is the nature of the evidence that well-being is linked to productivity? (iv) what is the state of knowledge on the effectiveness of interventions to promote workplace well-being? (v) should interventions aimed at improving well-being at work focus on more than work-related factors?

\section{Is there a robust and usable definition of well- being?}

Numerous definitions of well-being exist by discipline. Although there is no consensus definition, a growing convergence toward common elements has been noted $(13,22,23,27-34)$. A key common element is that well-being is more than merely the absence of negative circumstances, such as illness; rather it also includes positive features such as the quality of a job or happiness with one's life. The definition advocated by Waddell \& Burton (31) is that well-being is "the subjective state of being healthy, happy, contented, comfortable, and satisfied with one's life." It includes physical, material, social, emotional (happiness), and development and activity dimensions. A more expansive definition also cited at the Helsinki conference is: "flourishing employees achieving their full potential for both their own benefit and that of the organization." Well-being at 
work is also influenced by mental and physical health, job security, organization of work, work engagement, worklife benefits, and wages $(22,3135-41)$. There is a relatively large literature on well-being in psychology involving three areas: (i) displeasure-pleasure, (2) anxiety-comfort, and (3) depression-enthusiasm (32, 34, $35)$. There are also definitions in the fields of economics, medicine, and health. Although there is no consensus definition, efforts have progressed to develop tools to measures or characterize well-being. One self-evaluation tool developed by the Finnish Institute of Occupational Health is currently being tested in various companies and may serve as a useful means of benchmarking wellbeing at work (33).

\section{Have the variables that influence well-being been aptly described?}

There has been some informative research on determinants of well-being. Warr (32) identified three categories of determinants: work-related, lifestyle, and personality. Well-being also has been categorized in terms of context (work) and context-free. Of particular importance is the need to assess how adverse work conditions affect well-being. This is particularly difficult in knowledge economies where uncertainty, job stress, and work organization are major factors in health $(25,26,36,42,43)$. Also, more research is needed on the determinants and consequences of well-being at the individual, organizational, and societal levels and such research should aim to quantify the determinant factors $(13,34)$. This need includes research to clarify and validate the relationships shown in figure 1.

Ultimately, if well-being is to be achieved, it may be necessary to conduct research as to what factors affect the risk to well-being. If the research is to be useful for guidance or regulation, the relationship between hazards to well-being and the exposure to them will need to be characterized so that risks can be anticipated over a range of exposures (work conditions and characteristics) or so that at least some analogistic approach to exposure-response characterization could be developed to discriminate between the levels of threat to well-being.

\section{What is the nature of evidence linking well-being to productivity?}

A growing body of literature links workforce wellbeing to productivity particularly in terms of health as a component of well-being $(5,9,14,15,18,44-48)$. In the simplest terms, sickness absence has been shown to directly affect productivity (49). However, the literature linking health or well-being to productivity generally has important methodological limitations with regard to measuring both well-being and productivity $(14,50-52)$.

A macroeconomic analysis of the impact of health on productivity clearly shows a positive slope when life expectancy of the population of countries is plotted against gross national income per capita. Tompa (14) revisited four pathways by which health may affect productivity in the labor market: (i) a healthy labor force may be more productive; (ii) individuals with longer life expectancies may choose to invest more in education and receive greater benefits; (iii) individuals with longer life expectancies may save more for retirements; and (iv) improvements in survival and health of young children may provide incentive for reduced fertility, increased labor force participation, and increased per capita income (53).

Tompa concluded that economic well-being in developed countries is a function of their competitiveness in international markets, which is dependent on the innovation and productivity of the workforce and influenced by characteristics and quality of their human capital (including education, skills, and health). Health is now recognized as a critical aspect of human capital $(14,54)$. To better inform policy-making at all levels, (workers, enterprise, and national), additional research will be needed to incorporate more refined measures of health that include functional status and mental health. Also, research to link other non-health aspects of wellbeing (eg, satisfaction with one's life) to productivity is needed. Health and more generally well-being can affect productivity through absenteeism and presenteeism (lack of full functioning and performance at work often due to the diminished health of workers). There is a growing literature on presenteeism, demonstrating its costs and relationship with productivity. However, more research is needed on the definition, determinants, and the consequences of productivity $(55,56)$.

Care should be taken in two specific areas when considering the role of well-being and productivity. First, well-being and productivity can be assessed at the individual, enterprise, and national levels, and multilevel analyses will ultimately be necessary to get a comprehensive view of all the important determinants and relationships $(14,57)$. Second, at the individual level, there is concern that linking well-being to productivity may devolve to "blaming the worker" for the poor performance of the enterprise without examining all the other major factors including employer responsibility. The potential for misinterpretation should not preclude assessment of the factors that link individual well-being and productivity, but rather it also should remind investigators to guard against a reductionist interpretation. This includes not thinking of workers as mere units of 
production to be fine-tuned and oiled to churn out more work. However, consideration of productivity in relation to well-being includes addressing workers' potential, aspirations, and satisfaction as well as the ability to accomplish work successfully.

\section{What is the state of knowledge on the effectiveness of interventions to promote workplace well-being?}

For the health component of well-being, there is a growing body of evidence on the effectiveness of workplace intervention for occupational outcomes (eg, musculoskeletal disorders, mental health) and personal factors (eg, smoking, being overweight) (58-64). Systematic reviews and clearinghouse efforts through the Cochrane Collaboration and other organized entities have made significant contributions to assessing the state of knowledge on particular interventions (65). As more is learned about determinants of well-being, research will need to be conducted on how to influence these determinants and the effectiveness of such interventions (66). It may be even more difficult to conduct research on the effectiveness of interventions relating to the non-health component (eg, satisfaction with one's life) and their economic impact. If increasing workability is to be a widespread goal, more people with disabilities and chronic health conditions must be able to work successfully. Thus, it will be important to consider what worker health protection/promotion programs and accommodations will meet their needs.

Finally, the most important aspect of any intervention targeting well-being should be to address the greatest number of workers. Most workers are employed by small and medium enterprises (SME). These enterprises often have fewer resources and less expertise in OSH (67-69). In controlling traditional hazards, with some notable exceptions, addressing SME has been the greatest shortcoming of the OSH community. For SME, it is not clear whether controlling traditional occupational hazards may be more easily accomplished than controlling hazards to well-being, since a holistic approach might be more readily instituted due to the social environment of those firms. Three efforts related to well-being in SME are needed. Firstly, a larger portion of research resources should be focused on SME. Secondly, the distinctions within SME should be researched and characterized. Too often, SME are viewed as homogeneous entities when in fact there are important differences in resources, capabilities, and limitations in businesses that may have 5, 15, 50, or 250 employees. SME of various sizes need to be studied and differences noted so that more effective interventions by organization size can be developed and utilized (67,
68). Finally, the business case should be used as a motivation, and OSH professionals need to be more aware of and proficient in speaking the language of business (65). Most SME research has involved focusing on developing informational products and exploring ways to reach this target group. The critical issue however, is employer motivation, and the business case is the most important but not the only issue in motivation. Various reviews of the economic aspects of OSH stress the need for strengthening research and the business case, and the need for more emphasis on developing economic data and arguments $(47,48,51,65)$.

\section{Should interventions aimed at improving well- being at work focus on more than work-related factors?}

The extensive body of literature that indicates well-being at work is part of a larger context strongly points to the need for interventions aimed at improving well-being at work to go beyond work-related factors $(12,46,70-78)$. A majority of workers' most prevalent and significant health conditions (eg, cardiovascular disease, cancer, obesity, diabetes, arthritis, substance abuse, and depression) are not caused solely by workplace hazards, but work can exacerbate many of these conditions $(17,48$, $71,77,78)$. Yet, work and non-work factors are generally treated separately. The compartmentalization of work and non-work is due in part to the historic development of the labor and employment contract to limit liability (79). Moreover, the line between work and non-work has been blurred by new forms of work organization and communication. A need exists to conduct more etiologic research that investigates the interaction of occupational and personal risk factors (ORF and PRF). Historically, etiologic research focused on main effects that relate to interest of investigators, the organization, or the funding source. Thus OSH investigations traditionally focused on ORF-disease associations and other factors were "noise," confounders, or effect modifiers. Similarly, for example, in smoking-related research, investigators studied smoking-disease associations and occupational hazards were "noise" or confounders. To address well-being, it is important that both ORF and PRF be studied and interactions clearly assessed. In many cases, both PRF and ORF can cause the same condition or disease. Often, if both are present, the subsequent pathology is more severe, appears more quickly, and leads to earlier disability. This, as well as other forms of interaction, is important information in developing intervention programs and planning interventions $(22,37,69,70,78)$.

It is evident in the published literature that a transition is needed from recognizing solely occupa- 
tional hazards to recognizing all (or at least the most important) factors that affect the health and well-being of workers (figure 2) $(6-11,71-78)$. By making this transition, the $\mathrm{OSH}$ community can better address the role of well-being in productivity and national economic health. There is value in viewing OSH in a new light, positioning it in the mainstream of dealing with critical national problems. Over the past 25 years, with some important and notable exceptions, OSH has been a marginal contributor in national debates and national growth. Although the field and profession, until recently, have been slow to acknowledge this marginality, decision-makers have not. Nevertheless, the OSH community is well-equipped and poised to address the impending demographic collision of more people depending on fewer workers (4). However, making this transition will not be easy. It will require interdisciplinary thinking by the profession and managers of OSH systems and services. Revamped training programs for OSH professionals will be needed.

All countries and, particularly at this time, developed countries have a great need for the OSH profession to address this demographic situation and accept the challenge. The most compelling reason that the $\mathrm{OSH}$ profession is best suited to address the "aging worker demographic" is because the critical aspects are work and the workforce, the principal focus of the field. However, the history of OSH also includes the separation of occupational health from mainstream healthcare and, in some cases, from mainstream public health. Additionally, the field is suffering from a diminishing workforce and academic base due, in part, to the lack of good quality data on the magnitude and burden of work-related disease and disability, which does not argue that this is an area for career investment (80). Finally, an image and perception problem exists. Young people considering entering a health field do not see OSH as highly relevant to the problems of the day. If the OSH field is going to accept the challenge to step into the breach of the coming demographic collision, it needs to reconfigure, reinvest in, and re-energize itself.

The acute problem of an aging workforce and the need to extend working life in many developed countries is resonant in the literature and punctuated by the work

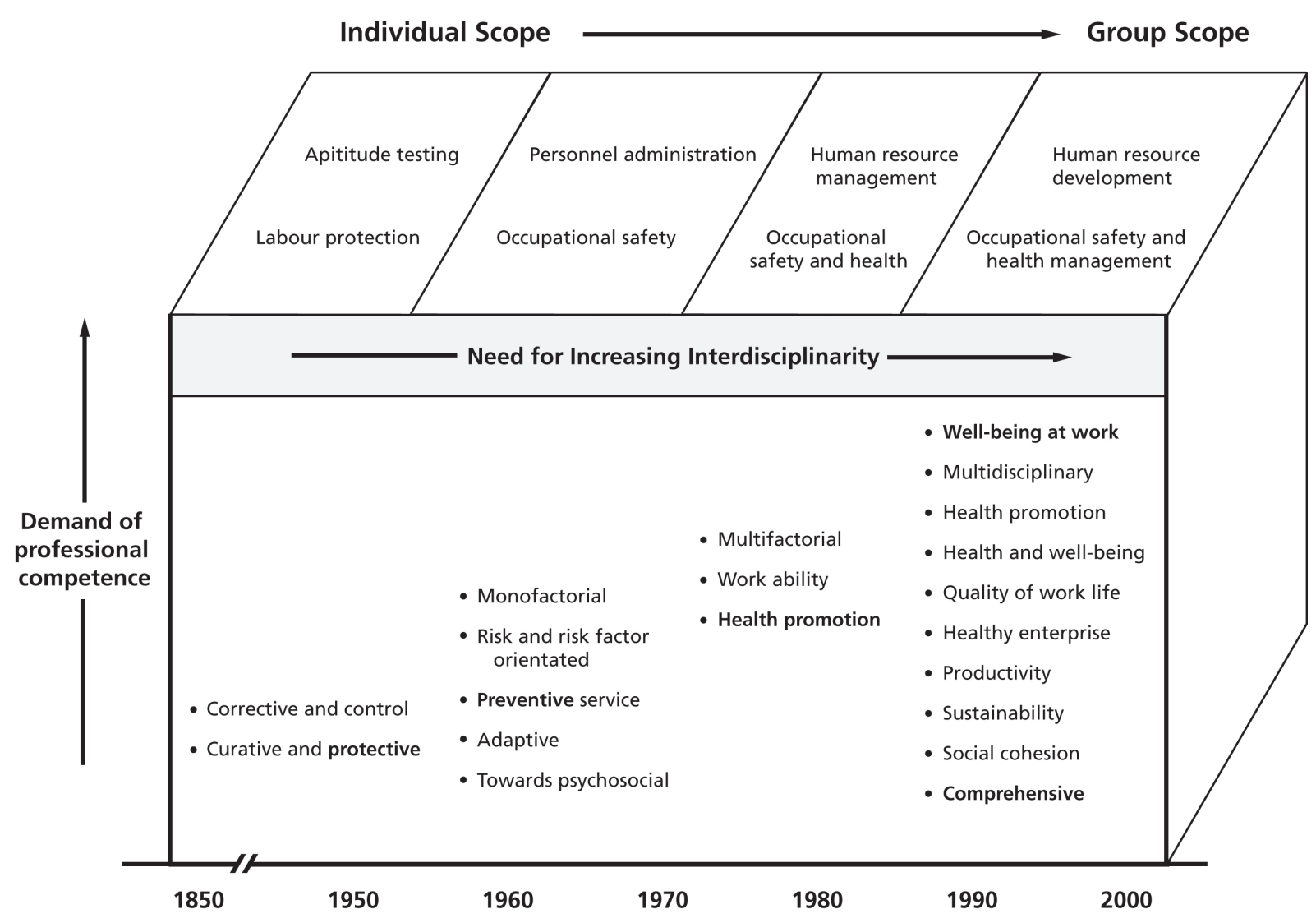

Figure 2. Evolution in focus on the health and well-being of the workforce. Adapted from Anttonen \& Räsänen (33) 
of Dame Carol Black who called for such reinvigoration. In recent years, the well-being at work of an aging workforce has been raised as an issue of corporate social responsibility and a focus for governments, labor, and academics $(4,6,13,17,21,80-82)$. Overall, in addressing well-being at work, the research needs are significant and the recent Helsinki conference on well-being at work can serve as a benchmark on the current status of the field and where it needs to go. There are many unanswered questions; this conference showed the progress in addressing them and what still needs to be accomplished.

\section{Acknowledgements}

The authors thank the following individuals for their comments on earlier drafts: Ben Amick, Gregory Wagner, Sheldon Samuels, Anasua Bhattacharya, Donald Eggerth, Ray Sinclair, Ann Brockhaus, Dori Reissman, Casey Chosewood, and David Wegman.

Disclaimer. The findings and conclusions in this report are those of the authors and do not necessarily represent the views of the National Institute for Occupational Safety and Health.

\section{References}

1. United Nations. World population: 1950-2050. Geneva: Population Division, Department of Economic and Social Affairs; 2002.

2. Tuljapurkar S, Li N, Boe C. A universal pattern of mortality decline in the G7 countries. Nature. 2000;405(6788):789-92.

3. Aura O, Ahonen G, Ilmarinen J. Strategisen hyvinvoinnin tila Suomessa, 2009 [Strategic well-being in Finland, 2009], Helsinki: Excenta Oy; 2009.

4. American College of Occupational and Environmental Medicine. Healthy workforce/healthy economy: the role of health, productivity, disability management in addressing the nation's healthcare crisis. J Occup Environ Med. 2009; (51):114-9.

5. Howard J. The future of work [Internet]. Slides presented at Safety and Health Issues in an Ageing Workforce panel discussion; 20092 July; Washington DC (USA): United States Department of Labor [cited 3 August 2010]. Available from: http://www.osha.gov/dcsp/smallbusiness/aging _ workforce.html.

6. Black C. Working for a healthier tomorrow. Norwich (UK): The Stationary Office; 2008.

7. Tuomi K, Ilmarinen J, Martikainen R, Aalto L, Klockars M. Aging, work, life-style and work ability among Finnish municipal workers in 1981-1992. Scand J Work Environ Health. 1997;23(suppl 1):58-65.
8. Rantanen J. Research challenges arising from changes in worklife. Scand J Work Environ Health. 1999;25(6):473-83.

9. Ilmarinen J, Tuomi K, Seitsamo J. New dimensions in workability. In: Costa G, Goedhard WSA, Ilmarinen J, editors. Assessment and promotional workability, health and wellbeing of ageing workers. Amsterdam: Elsevier; 2005. p 3-7.

10. Kuoppala J, Lamminpää A, Husman P. Work health promotion, job well-being, and sickness absences-a systematic review and meta-analysis. J Occup Environ Med. 2008; 50(11):1216-27.

11. Nordenfelt L. The concept of work ability. Brussells: Peter Lang Publishing Group; 2008.

12. Amick B 3rd, Lavis JN. Labour markets and health: a framework and set of applications. Toronto: Institute for Work and Health; 1999. Working Paper number 71.

13. Hassan E, Austin C, Claire C, Disley E, Hunt P, Marjanovic S, et al. Health and well-being at work in the United Kingdom. Santa Monica (CA): Rand Corporation; 2009.

14. Tompa E. The impact of health on productivity: macro and microeconomic evidence and policy implications. In: Sharpe A, St-Hilaire F, Banting K, editors. The review of economic performance and social progress 2002: towards a social understanding of productivity. Montreal: Institute for Research on Public Policy; 2002. p 181-202.

15. Amick B 3rd, Gimeno D. Measuring work outcomes with a focus on health-related work productivity loss. In: Wittink $\mathrm{H}$, Carr D, editors. Evidence outcome and quality of life in pain treatment: a handbook for pain treatment professionals. Edinburgh (UK): Elsevier; 2008.

16. Shrestha L. Age dependency ratios and social security solvency: CRS Report for Congress RL 32951. Washington (DC): Congressional Research Service; 2006.

17. Society for Occupational and Environmental Health (SOEH). Healthy aging for a sustainable workforce: a conference report [Internet]. Silver Spring (MD): SOEH; 2009 [cited 3 August 2010]. Available from: http://www. soeh.org/pdf/AgingWorkers WorkshopReport_11\%20 09_Final.pdf

18. Davis K, Collins SR, Doty MM, Ho A, Holmgren AL. Health and productivity among U.S. workers [Internet]. New York (NY): Commonwealth Fund; 2005 [cited 25 May 2010]. Available from: http://www.commonwealthfund.org/ Content/Publications/Issue-Briefs/2005/Aug/Health-andProductivity-Among-U-S--Workers.aspx

19. Friedland R, Summer L. Demography is not destiny, revisited. Washington (DC): National Academy on an Aging Society; 2005. Commonwealth Fund Publication 789.

20. Verdugo RR. Workers, workers' productivity and the dependency ratio in Germany: analysis with implications for social policy. Popul Res Policy Rev. 2006;25(5-6):547-65.

21. Tehrani N, Humpage S, Willmott B, Haslam I. What's happening with well-being at work [Internet]. London (UK): Chartered Institute of Personnel and Development; 2007 [cited 3 August 2010]. Available from: http://www. cipd.co.uk/NR/rdonlyres/DCCE94D7-781A-485A-A7026DAAB5EA7B27/0/whthapwbwrk.pdf 
22. Muse L, Harris SG, Giles WE, Feild HS. Work-life benefits and positive organizational behavior: is there a connection? J Organ Behav. 2008;29(2):171-92.

23. Waddell G, Burton K, Aylward M. Work and common health problems. J Insur Med. 2007;39(2):109-20.

24. Schaufeli WB, Bakker AB, Van Rhenen W. How changes in job demands and resources predict burnout, work engagement, and sickness absenteeism. J Organ Behav. 2009;30(7):893-917.

25. Kieselbach T, Winefield AH, Boyd C, Anderson S, editors. Unemployment and health: international and interdisciplinary perspective. Bowen Hills (Australia): Australian Academic Press; 2006.

26. Lundin A, Lundberg I, Hallsten L, Ottosson J, Hemmingsson T. Unemployment and mortality - a longitudinal prospective study on selection and causation in 49321 Swedish middleaged men. J Epidemiol Community Health. 2010;64(1):22-8.

27. Guyatt GH, Feeny DH, Patrick DL. Measuring health-related quality of life. Ann Intern Med 1993:118(8):622-9.

28. Sumner LW. Welfare, happiness, and ethics. New York (NY): Oxford University Press; 1996.

29. Warr P. Work, happiness, and unhappiness. Mahwah (NJ): Lawrence Erlbaum Associates, Inc; 2007.

30. Blanchflower DG, Oswald, AJ. Well-being over time in Britain and the USA. Cambridge (MA): National bureau of Economic Research (NBER); 2000. NBER Working Paper 7487.

31. Waddell G, Burton AK. Is work good for your health and wellbeing? London: The Stationary Office; 2006.

32. Warr P. Well-being and the workplace. In: Kahneman D, Diener E, Schwarz N, editors. Well-being: foundations of hedonic psychology. New York (NY): Russell Sage Foundation; 1999. p 392-412.

33. Anttonen $\mathrm{H}$, Räsänen T, editors. Well-being at work - new innovations and good practices. Helsinki: Finnish Institute of Occupational Health; 2009.

34. Danna K, Griffin RW. Health and well-being in the workplace: a review and synthesis of the literature. J Manage. 1999;25(3):357-84.

35. Warr P. The measurement of well-being and other aspects of mental-health. J Occup Psychol. 1990;63(3):193-210.

36. Green F. Work intensification, discretion, and the decline in well-being at work. East Econ J. 2004;30(4):615-25.

37. Cooper CL. Mental health and well being at work: the disposal workforce. Int J Public Health. 2008;53(5):225-6.

38. Xanthopoulou D, Bakker AB, Demerouti E, Schaufeli WB. Reciprocal relationships between job resources, personal resources, and work engagement. J Vocat Behav. 2009; 74(3):235-44.

39. Halbesleben J, Harvey J, Bolino MC. A conservation of resources view of the relationship between work engagement and work interference with family. J Appl Psychol. 2009;94(6):1452-65.

40. Gautie J, Schmitt J, editors. Low wage work in the wealthy world. New York (NY): Russell Sage Foundation; 2009.

41. Layard R. Measuring subjective well-being. Science. 2010;327(5965):534-55.
42. Karoly LA, Panis CWA. The $21^{\text {st }}$ century at work: forces shaping the future workforce and workplace in the United States. Santa Monica (CA): Rand Corporation; 2005.

43. commissiononhealth.org [Internet]. Washington DC (USA): Robert Wood Johnson Foundation. Commission to Build a Healthier America; Feb 2008-Dec 2009 [cited 25 May 2010]. Available from: http://www. commissiononhealth.org/

44. Burton WN, Conti DJ, Chen CY, Schultz AB, Edington DW. The role of health risk factors and disease on worker productivity. J Occup Environ Med. 1999:41(10): 863-77.

45. McCunney RJ. Health and productivity: a role for occupational health professionals. J Occup Environ Med. 2001;43(1):30-5.

46. Bolge SC, Doan JF, Kannan H, Baran RW. Association of insomnia with quality of life, work productivity, and activity impairment. Qual Life Res. 2009;18(4):415-22.

47. Loeppke R, Taitel M, Haufle V, Parry T, Kessler RC, Jinnett K. Health and productivity as a business strategy: a multiemployer study. J Occup Environ Med. 2009;51(4):411-28.

48. Goetzel RZ, Ozminkowski RJ, Pelletier KR, Metz RD, Chapman LS. Emerging trends in health and productivity management. Am J Health Prom. 2007;22(1):A1-A7.

49. Pauly MV, Nicholson S, Xu J, Polsky D, Danzon PM, Murray JF. A general model of the impact of absenteeism on employers and employees. Health Econ. 2002;11(3):221-31.

50. Beaton D, Bombardier C, Escorpizo R, Zhang W, Lacaille D, Boonen A, et al. Measuring worker productivity: frameworks and measures. J Rheumatol. 2009; 36(9):2100-9.

51. Uegaki K, de Bruijne MC, Anema JR, van der Beek AJ, van Tulder MW, van Mechelen W. Consensus-based findings and recommendations for estimating the costs of health-related productivity loss from a company's perspective. Scand J Work Environ Health. 2007; 33(2):122-30.

52. Page K, Vella-Brodrick D. The 'what', 'why' and "how' of employee well-being: a new model. Soc Indic Res. 2009;90(3):441-58.

53. Bloom DE, Canning D. Policy forum: public health - the health and wealth of nations. Science. 2000;287:1207-09.

54. Grossman M . The human capital model. In: Culyer AJ, Newhouse JP, editors. Handbook of health economics. Amsterdam: Elsevier. 2000. p 347-408.

55. Schultz AB, Edington DW. Employee health and presenteeism: A systematic review. J Occup Rehabil. 2007;17(3):547-79.

56. Bergstrom G, Bodin L, Hagberg J, Aronsson G, Josephson M. Sickness presenteeism today, sickness absenteeism tomorrow?: a prospective study on sickness presenteeism and future sickness absenteeism. J Occup Environ Med. 2009;51(6):629-38.

57. Ilies R, Schwind KM, Heller D. Employee well-being; a multilevel model linking work and nonwork domains. Eur J Work Organ Psychol. 2007;16(3):326-41.

58. Westgaard RH, Winkel J. Ergonomic intervention research for improved musculoskeletal health: a critical review. Int J Ind Ergon. 1997;20(6):463-500. 
59. Sorensen G. Smoking cessation at the worksite: what works and what is the role of occupational health? In: Health National Institute for Occupational Safety and Health, editor. Work, smoking, and health: A NIOSH scientific workshop. Cincinnati $(\mathrm{OH})$ : US Department of Health and Human Services, Public Health Service, Centers For Disease Control and Prevention, National Institute for Occupational Safety and Health; 2002. DHHS (NIOSH) Publication No 2002-148, p 99-120.

60. Yeow PHP, Sen RN. Quality, productivity, occupational health and safety and cost effectiveness of ergonomic improvements in the test workstations of an electronic factory. Int J Ind Ergon. 2003;32(3):147-63.

61. Li J, Wolf L, Evanoff B. Use of mechanical patient lifts decreased musculoskeletal symptoms and injuries among health care workers. Inj Prev. 2004;10(4):212-6.

62. Leino T, Olsson K. Workplace health promotion - practice and evaluation. Helsinki: Finish Institute of Occupational Health; 2004.

63. Katz DL, O'Connell M, Yeh MC, Nawaz H, Njike V, Anderson LM, et al. Public health strategies for preventing and controlling overweight and obesity in school and worksite settings: a report on recommendations of the Task Force on Community Preventive Service. MMWR Recomm Rep. 2005;54(RR-10):1-12.

64. Harvey S, Couray F, Petit A, Hudon J, Teed M, Loisell O, et al. Organizational interventions and mental health in the workplace: a synthesis of international approaches. Montreal: Institut de recherche Robert-Sauvé en santé et en sécurité du travail; 2006. Studies and Research Projects, report 480.

65. Verbeek J, Pulliainen M, Kankaanpää E. A systematic review of occupational safety and health business cases. Scand J Work Environ Health. 2009;35:403-12.

66. Schulte PA, Goldenhar LM, Connally LB. Intervention research: science, skills, strategies. Am J Ind Med. 1996;29:285-88.

67. Okun A, Lentz TJ, Schulte P, Stayner L. Identifying high-risk small business industries for occupational safety and health interventions. Am J Ind Med. 2001;39(3):301-11.

68. Champoux D, Brun JP. Occupational health and safety management in small size enterprises: an overview of the situation and avenues for intervention and research. Saf Sci. 2003;41(4):301-18.

69. MacEachen E, Breslin FC, Kyle N, Irvin E, Kosny A, Bigelow $\mathrm{P}$, et al. Effectiveness and implementation of health and safety programs in small enterprises: a systematic review of quantitative and qualitative literature. Toronto (Canada): Institute for Work and Health; 2008.

70. Sorensen G, Barbeau E. Steps to a healthier US workforce: integrating occupational health and safety and worksite health promotion: state of the science [Internet]. Washington (DC): US Department of Health and Human Services, Public Health Service, Centers For Disease Control and Prevention, National Institute for Occupational Safety and Health [cited 25 May 2010]. Available from: http://www.cdc.gov/niosh/worklife/ steps/2004/default.htm.

71. Wynne-Jones G, Buck R, Varnava A, Phillips C, Main CJ. Impacts on work absence and performance: what really matters? Occup Med (Lond). 2009;59(8):556-62.

72. Soler RE, Leeks KD, Razi S, Hopkins DP, Griffith M, Aten A, et al. A systematic review of selected interventions for worksite health promotion. Am J Prev Med. 2010;38(2):S237-S262.

73. Levenstein C. Worksite health promotion [editorial]. Am J Public Health. 1989;79(1):11

74. Dejoy DM, Southern DJ. An integrative perspective on work-site health promotion. J Occup Environ Med 1993;35(12):1221-30.

75. European Network for Workplace Health Promotion (ENWHP). The Luxembourg declaration on workplace health promotion in the European Union [Internet]. ENWHP; 1997; [cited 7 June 2010]. Available from: http://www.enwhp.org/ fileadmin/downloads/press/Luxembourg_Declaration June2005 final.pdf

76. Hämäläinen R. Workplace health promotion in Europe the role of national health policies and strategies. Helsinki: Finnish Institute of Occupational Health. 2007.

77. el Batawi MA. Work-related diseases - a new program of the world-health-organization. Scand J Work Environ Health. 1984;10:341-6.

78. Munir F, Khan HTA, Yarker J, Haslam C, Long H, Bains M, et al. Self-management of health-behaviors among older and younger workers with chronic illness. Patient Educ Couns. 2009;77(1):109-15.

79. Ringen K, Smith WJ. Occupational disease and equity issues. Virgina Natural Resource Law Journal. 1982;2:213-31.

80. Schulte PA. Characterizing the burden of occupational injury and disease. J Occup Environ Med. 2005;47(6):607-22.

81. CSR Europe [Internet]. Brussels: CSR Europe; c2008 [cited 4 August 2010]. CSR Laboratory on wellbeing in the workplace. Available from: http://www.csreurope.org/pages/ en/wellbeing.html.

82. Leibold M, Voelpel M. Managing the aging workforce: challenges and solutions. Erlangen: Publicis Corporate Publishing/Wiley-VCH-Verlag GmbH \& Co KgaA; 2006.

Received for publication: 10 June 2010 